\title{
PERFORMANCE ANALYSIS OF CORRUGATED PLATE HEAT EXCHANGER WITH WATER AS WORKING FLUID
}

\author{
Tisekar Salman W1, Mukadam Shakeeb A ${ }^{2}$, Vedpathak Harshad S ${ }^{3}$, Rasal Priyanka K ${ }^{4}$, \\ Khandekar S. B ${ }^{5}$ \\ ${ }^{1}$ Student of B.E., Mechanical Engineering, Rajendra Mane College of Engineering and Technology, Devrukh, \\ Maharashtra, India. \\ ${ }^{2}$ Student of B.E., Mechanical Engineering, Rajendra Mane College of Engineering and Technology, Devrukh, \\ Maharashtra, India. \\ ${ }^{3}$ Student of B.E., Mechanical Engineering, Rajendra Mane College of Engineering and Technology, Devrukh, \\ Maharashtra, India. \\ ${ }^{4}$ Student of B.E., Mechanical Engineering, Rajendra Mane College of Engineering and Technology, Devrukh, \\ Maharashtra, India. \\ ${ }^{5}$ Assistant Professor, Mechanical Engineering, Rajendra Mane College of Engineering and Technology, Devrukh, \\ Maharashtra, India.
}

\begin{abstract}
Heat exchangers are devices that provide the exchange of heat between two same or distinguished fluids that are at different temperature without mixing them with each other. Plate heat exchanger is one such compact heat exchanger, provides more heat transfer between two fluids in comparison with shell and tube heat exchanger. This study is focused on use of corrugated plate heat exchanger (PHE) for water as a working fluid. This research work deals with experimental investigation of corrugated type of PHE with evaluation of convective heat transfer coefficient, overall heat transfer coefficient and exchanger effectiveness. Heat exchanger for carrying out this work consists of thin metal brazed plates of stainless steel with 0.5mm thickness, plates with rectangular geometry and corrugations on plate surface with chevron angle $45^{\circ} / 45^{0}$, plate spacing of $2.24 \mathrm{~mm}$ and with 14 number of plates. Tests are conducted by varying operating parameters like mass flow rate of hot water, inlet temperatures of hot water. The main objective of this work is to find out effects of these parameters on performance of heat exchangers with parallel and counter flow arrangements. Results show that convective heat transfer coefficient increases with increase in mass flow rate and Reynolds number. Also the effectiveness varies with the mass flow rate of hot water. In this study, maximum effectiveness achieved for parallel flow arrangement with water as a working fluid is 0.67 and that of counter flow arrangement is 0.82 . Use of plate heat exchanger is more advantageous than the tube type heat exchanger with same effectiveness as it occupies less space.
\end{abstract}

Keywords: Plate Heat Exchanger (PHE), Convective Heat Transfer Coefficient, Reynolds Number, Exchanger Effectiveness.

\section{INTRODUCTION}

Heat exchangers are specifically used for exchange of heat between two same or distinguished fluids that are at different temperatures, and also it avoids mixing of those two fluids. The criterion for classifying the heat exchanger as Compact heat exchanger is ratio of a high wetted surface area (heat transfer area) to unit volume. Necessarily, it should be higher than $100 \mathrm{~m}^{2} / \mathrm{m}^{3}$ for heat exchangers to be compact one. [4] The plate heat exchanger has got wide range of applications from chemical industries to marine and food industries as well, due to it's associated merits such as it occupies less space, light in weight, low cost, less energy consumption and high rate of heat transfer.

Plate heat exchangers can be sub divided into four types as mentioned below: [4]

i. Plate- and- frame heat exchangers

ii. Spiral heat exchangers iii. Plate coil heat exchangers

iv. Plate fin heat

Another criterion for classification of PHE is type of sealing. There three types of sealing such as Gasketed, brazed and welded. Each type of sealing provides certain advantages over the use of other. Gasketed plate heat exchangers (PHEs) prove beneficial from maintenance and cleaning point of view. In addition to this, it shows better heat transfer characteristics by addition or removal of the plates. In brazed type of PHE, the unique flow system insures continuous flow around the port area which feeds the working fluid equally over the channel to guarantee maximum use of the heat transfer area. The Rolled Edge Lock System guarantees a consistent braze joint at the plate overlap and makes for stronger and more leak-proof heat exchanger. The contact points, extended and larger in design, result in stronger braze joints between the plates, thus guaranteeing high heat exchanger strength. 
In detail literature review on corrugated PHE is discussed below.

\section{LITERATURE REVIEW}

R. K. Shah and S. G. Kandilkar (1989) [2] had presented classification of PHE on the basis of number of passes, flow arrangement and by considering end plate effect. Configurations used for this study were 1-1 (1 Pass-1 Pass), 2-1, 2-2, 3-3, 4-1,4-2, and 4-4 arrangements, and six configurations for the 3-1 arrangement. Results were presented for temperature effectiveness, log-mean temperature difference correction factor as a function of number of transfer units, heat capacity ratio and total number of thermal plates. Also this study provide guidelines for selection of appropriate PHE configuration.

Jogi Nikhil G., Lawankar Shailendra M (2012) [3] had reviewed effect of plate geometry on heat transfer characteristics of corrugated PHE.

Murugesan M.P. and Balasubramani R. (2013) [4] had investigated experimentally heat transfer enhancement in PHE with regard to effects of various operating and design parameters. In this study tests are conducted on plate pack of length $31 \mathrm{~mm}$ with $100^{\circ} \mathrm{C}$ work temperature and design pressure $6 \mathrm{~kg} / \mathrm{cm}^{2}$. The parameters such as flow rates, temperature, pressure and properties of test fluid were varied. The outcomes of this study were overall heat transfer coefficient and individual heat transfer coefficient increases with mass flow rate.

Vishal R. Naik, V.K. Matawala (2013) [5] had studied experimentally the effect of chevron angle with wide range of Reynolds Number on heat transfer characteristics of Gasketed oil-water PHE. Results showed that increase in mass flow rate of both the fluids increases overall heat transfer coefficient. In addition to this $60^{\circ}$ chevron angles gives better heat transfer coefficient for wide range of Reynolds number.

T K S Sai Krishna, S G Rajasekhar, C Pravarakhya (2013) [6] For many industrial applications plate heat exchangers are demonstrating a large superiority over the other types of heat exchangers. In this they performed analysis using two different working fluids which are i.e. $\mathrm{CO}_{2}$ and $\mathrm{R} 134_{\mathrm{a}}$ used only for refrigeration system. They got the results regarding heat transfer and also observed a very low pressure drop.By knowing the inlet conditions like mass flow rate, temperature, pressure of both hot and cold fluid streams, and performed CFD analysis in ANSYS software. The optimal design of multi-pass plate type heat exchanger is designed by optimizing the variables such as number of passes for both streams, no. of plates, plate type and size.

Masoud Asadi, Ramin Haghighi Khoshkhoo (2014) [7] had demonstrated effect of chevron angle on heat transfer coefficient, friction factor and pressure drop of corrugated PHE. From this study it was concluded that, optimal value of cheveron angle is $60^{\circ}$ and friction factor varies inversely with mass flow rate of both fluids in laminar and turbulent zone.
This paper focuses on thermal design of corrugated PHE for one pass one arrangement and water-water heat transfer. The main objective of this research work is to investigate performance of corrugated PHE with regard to overall heat transfer coefficient, effectiveness and the effect of mass flow rate and flow arrangement on the performance of corrugated PHE.

\section{METHODOLOGY}

\subsection{Thermal Design}

Design procedure of heat exchanger involves rating and sizing of heat exchanger. Rating problem deals with determination rate of heat transfer, heat transfer coefficient, outlet temperature. Sizing problem involves selection of plate material, flow arrangement, determining physical size of heat exchanger to meet specified heat transfer. When sizing a PHE, there is very little choice in the selection of plate dimensions, unlike plate-fin and tube-fin heat exchanger designs, because it is difficult to select arbitrarily a plate width (W) or plate length (L). Instead, plate size selection should be based on available plate sizes from any manufacturer. As the dies used for forming the plates are extremely expensive, each manufacturer offers only up to about 30 plate sizes. [1]

This heat exchanger design involves calculation of heat transfer coefficient and number of plates with the following information:

Plate specifications from manufacturer:

Plate height $(\mathrm{H})=231 \mathrm{~mm}$,

Plate width $(\mathrm{W})=90 \mathrm{~mm}$,

Plate thickness $(\mathrm{t})=0.5 \mathrm{~mm}$,

Plate spacing $(b)=2.24 \mathrm{~mm}$,

Material of the plate $=$ Stainless Steel (AISI 316).

Input data:

Hot water inlet temp $=85^{\circ} \mathrm{C}$,

Hot water outlet temp $=65^{\circ} \mathrm{C}$,

Cold water inlet temp $=25^{\circ} \mathrm{C}$,

Mass flow rate of hot water $m_{h}=0.25 \mathrm{~kg} / \mathrm{sec}$,

Mass flow rate of cold water $\mathrm{m}_{\mathrm{c}}=0.25 \mathrm{~kg} / \mathrm{sec}$.

\subsubsection{Heat Duty (Q)}

Mathematically it is given as,

$Q=m_{h} C_{p h} \Delta T_{h}$

Heat rejected by hot water

$Q=m_{h} C_{p h}\left(T_{h 1}-T_{h 2}\right)$
$Q=0.25 \times 4194 \times(85-65)$

$Q=20970 \mathrm{~W}$

Where,

$\mathrm{m}_{\mathrm{h}}=$ mass flow rate of hot water in $\mathrm{Kg} / \mathrm{s}$, 
$\mathrm{C}_{\mathrm{ph}}=$ specific heat capacity of hot water $\mathrm{J} / \mathrm{Kg} \mathrm{K}$,

$\Delta \mathrm{T}_{\mathrm{h}}=$ temperature difference between inlet and outlet of hot water in $\mathrm{K}$.

Heat absorbed by cold water

$Q=m_{c} C_{p c} \Delta T_{c}$

$Q=m_{c} C_{p c}\left(T_{c 2}-T_{c 1}\right)$

$20970=0.25 \times 4178\left(T_{c 2}-25\right)$

$T_{c 2}=45.07^{\circ} \mathrm{C}$

Where,

$\mathrm{m}_{\mathrm{c}}=$ mass flow rate of cold water in $\mathrm{Kg} / \mathrm{s}$,

$\mathrm{C}_{\mathrm{pc}=}$ specific heat capacity of hot water in $\mathrm{J} / \mathrm{Kg} \mathrm{K}$,

$\Delta \mathrm{T}_{\mathrm{c}}=$ temperature difference between inlet and outlet of cold water in $\mathrm{K}$.

Hot water mean temp $=\frac{85+65}{2}=75^{\circ} \mathrm{C}$

Cold water mean temp $=\frac{25+45.07}{2}=35.03^{\circ} \mathrm{C}$

Table-1: Thermo physical properties of fluids

\begin{tabular}{|l|l|l|l|}
\hline Property & $\begin{array}{l}\text { Unit } \\
\text { (metric) }\end{array}$ & $\begin{array}{l}\text { Hot water } \\
\text { (mean } \\
\text { temp- } \\
\text { erature) }\end{array}$ & $\begin{array}{l}\text { Cold } \\
\text { water } \\
\text { (mean } \\
\text { temp- } \\
\text { erature) }\end{array}$ \\
\hline $\begin{array}{l}\text { Heat capacity } \\
\left(C_{\mathrm{p})}\right.\end{array}$ & $\mathrm{J} / \mathrm{kgK}$ & 4197 & 4178 \\
\hline $\begin{array}{l}\text { Thermal } \\
\text { conductivity }(\mathrm{k})\end{array}$ & $\mathrm{W} / \mathrm{mk}$ & 0.668 & 0.6316 \\
\hline $\begin{array}{l}\text { Dynamic } \\
\text { viscosity }(\mu)\end{array}$ & $\mathrm{Ns} / \mathrm{m}^{2}$ & 0.000378 & 0.000720 \\
\hline Density $(\rho)$ & $\mathrm{Kg} / \mathrm{m}^{3}$ & 974.851 & 994.034 \\
\hline
\end{tabular}

3.1.2 The Hydraulic Diameter:

$$
\begin{aligned}
D_{e} & =\frac{2 b}{\psi} \ldots \ldots \ldots \ldots \ldots \\
& =\frac{2 \times 0.00224}{1.16} \\
D_{e} & =0.00386 \mathrm{~m}
\end{aligned}
$$

\subsubsection{The Flow Area For Water:}

$$
A=\mathrm{NWb}
$$

Where,

$\mathrm{A}=$ flow area for water in $\mathrm{m}^{2}$,

$\mathrm{N}=$ number of water chambers,

$\mathrm{W}=$ width of plate in $\mathrm{m}$,

$\mathrm{b}=$ distance between two plates in $\mathrm{m}$.
For hot water:

$A_{h}=N_{h} W b$

Here,

$\mathrm{N}_{\mathrm{h}}=6, \mathrm{~W}=0.090 \mathrm{~m}, \mathrm{~b}=0.00224 \mathrm{~m}$

$A_{h}=6 \times 0.090 \times 0.00224$

$A_{h}=0.0012 m^{2}$

For cold water:

$A_{c}=N_{c} W b$

Here,

$\mathrm{N}_{\mathrm{h}}=7, \mathrm{~W}=0.090 \mathrm{~m}, \mathrm{~b}=0.00224 \mathrm{~m}$

$A_{c}=7 \times 0.090 \times 0.00224$

$A_{c}=0.001411 m^{2}$

\subsubsection{Velocity of Water}

$V=\frac{m}{A \rho}$

Where

$\mathrm{V}=$ velocity of hot water in $\mathrm{m} / \mathrm{s}$,

$\mathrm{m}=$ mass flow rate in $\mathrm{Kg} / \mathrm{s}$

$\mathrm{A}=$ flow area for water in $\mathrm{m}^{2}$,

$\rho_{=}$density of water in $\mathrm{Kg} / \mathrm{m}^{3}$

For hot water:

$V_{h}=\frac{m_{h}}{A_{h} \rho_{h}}$

Here,

$\mathrm{m}_{\mathrm{h}}=0.25 \mathrm{Kg} / \mathrm{s}, \mathrm{A}_{\mathrm{h}}=0.0012 \mathrm{~m}^{2}, \rho_{\mathrm{h}}=974.851 \mathrm{Kg} / \mathrm{m}^{3}$

$=\frac{0.25}{0.0012 \times 974.851}$

$V_{h}=0.2137 \mathrm{~m} / \mathrm{s}$

For cold water:

$V_{c}=\frac{m_{c}}{A_{c} \rho_{c}}$

Here,

$\mathrm{m}_{\mathrm{c}}=0.25 \mathrm{Kg} / \mathrm{s}, \mathrm{A}_{\mathrm{c}}=0.001411 \mathrm{~m}^{2}, \rho_{\mathrm{c}}=994.034 \mathrm{Kg} / \mathrm{m}^{3}$

$=\frac{0.25}{0.001411 \times 994.034}$
$V_{c}=0.1783 \mathrm{~m} / \mathrm{s}$

\subsubsection{Reynolds Number}

For hot water:

$$
R e_{h}=\frac{\rho_{h} V_{h} D_{e}}{\mu_{h}}
$$

Here,

$\rho_{\mathrm{h}}=974.851 \mathrm{Kg} / \mathrm{m}^{3}, \mathrm{~V}_{\mathrm{h}}=0.2137 \mathrm{~m} / \mathrm{s}$,

$\mathrm{De}=0.00386 \mathrm{~m}, \mu_{\mathrm{h}}=0.000378 \mathrm{Ns} / \mathrm{m}^{2}$ 


$$
\begin{gathered}
=\frac{974.851 \times 0.2137 \times 0.00386}{0.000378} \\
R e_{h}=2127.34
\end{gathered}
$$

\section{For Cold Water:}

$R e_{c}=\frac{\rho_{c} V_{c} D_{c}}{\mu_{c}}$

Here,

$\rho_{\mathrm{c}}=994.034 \mathrm{Kg} / \mathrm{m}^{3}, \mathrm{~V}_{\mathrm{c}}=0.1783 \mathrm{~m} / \mathrm{s}$,

$\mathrm{D}_{\mathrm{e}}=0.00386 \mathrm{~m}, \mu_{\mathrm{h}}=0.000720 \mathrm{Ns} / \mathrm{m}^{2}$

$$
=\frac{994.034 \times 0.1783 \times 0.00386}{0.000720}
$$

\subsubsection{Prandtl Number:}

For hot water:

$P r_{h}=\frac{\mu_{h} C_{p h}}{k_{h}}$

Here,

$\mu_{\mathrm{h}}=0.000378 \mathrm{Ns} / \mathrm{m}^{2}, \mathrm{C}_{\mathrm{ph}}=4194 \mathrm{~J} / \mathrm{Kg} \mathrm{K}$,

$\mathrm{k}_{\mathrm{h}}=0.668 \mathrm{~W} / \mathrm{mK}$.

$$
=\frac{0.000378 \times 4194}{0.668}
$$

$P r_{h}=2.3732$

For cold water:

$P r_{c}=\frac{\mu_{c} C_{p c}}{k_{c}}$

Here,

$\overbrace{\mathrm{c}}=0.000720 \mathrm{Ns} / \mathrm{m}^{2}, \mathrm{C}_{\mathrm{pc}}=4.178 \mathrm{~J} / \mathrm{Kg} \mathrm{K}$,

$\mathrm{k}_{\mathrm{c}}=0.6316 \mathrm{~W} / \mathrm{mK}$

$$
\begin{gathered}
=\frac{0.000720 \times 4.178}{0.6316} \\
P r_{c}=4.7627
\end{gathered}
$$

\subsubsection{Nusselt Number}

Here, $R e>2000$ so taking relation for turbulent flow,

$\mathrm{Nu}=0.662 \operatorname{Re}^{0.5} \mathrm{Pr}^{0.33}$

\section{For hot water:}

$N u_{h}=0.662 R e_{h}{ }^{0.5} P r_{h}{ }^{0.33}$

Convective heat transfer coefficient for hot water $\left(h_{h}\right)$ :

$h_{h}=(0.662)\left(\frac{k_{h}}{D_{e}}\right) R e_{h}{ }^{0.5} P r_{h}{ }^{0.33}$

Here,

$\mathrm{k}_{\mathrm{h}}=0.668 \mathrm{~W} / \mathrm{mK}, \mathrm{Re}_{\mathrm{h}}=2127.34, \operatorname{Pr}_{\mathrm{h}}=2.3732$
$=0.662 \times\left(\frac{0.668}{0.00386}\right) \times(2127.34)^{0.5} \times(2.3732)^{0.33}$

$h_{h}=7027.90 \mathrm{~W} / \mathrm{m}^{2} . \mathrm{K}$

Where,

$h_{h}$ is the hot fluid heat transfer coefficient

For cold water

$N u_{c}=0.662 R e_{c}^{0.5} \operatorname{Pr}_{c}^{0.33}$

Convective heat transfer coefficient $\left(\mathrm{h}_{\mathrm{c}}\right)$ :

$h_{c}=(0.662)\left(\frac{k_{c}}{D_{e}}\right) R e_{c}{ }^{0.5} \operatorname{Pr}_{c}{ }^{0.33}$

Here,

$\mathrm{K}_{\mathrm{c}}=0.6316 \mathrm{~W} / \mathrm{mK}, \operatorname{Re}_{\mathrm{c}}=950.18, \operatorname{Pr}_{\mathrm{c}}=4.7627$

$=(0.662) \times\left(\frac{0.6316}{0.00386}\right) \times(950.18)^{0.5} \times(4.7627)^{0.33}$

$h_{c}=5588.65 \mathrm{~W} / \mathrm{m}^{2} \mathrm{~K}$

\subsubsection{Overall Heat Transfer Co-Efficient:}

The overall heat transfer coefficient for a clean surface is given by,

$\frac{1}{U}=\frac{1}{h_{h}}+\frac{t}{k_{p}}+\frac{1}{h_{c}}$

Here,

$\mathrm{h}_{\mathrm{h}}=7027.90 \mathrm{~W} / \mathrm{m}^{2} . \mathrm{K}, \mathrm{h}_{\mathrm{c}}=5588.65 \mathrm{~W} / \mathrm{m}^{2} . \mathrm{K}$,

$\mathrm{K}_{\mathrm{p}}=17.5 \mathrm{~W} / \mathrm{mk}, \mathrm{t}=0.0005 \mathrm{~m}$

$=\frac{1}{7027.9}+\frac{0.0005}{17.5}+\frac{1}{5588.65}$

$\frac{1}{U}=0.0003497$

$U=2858.81 \mathrm{~W} / \mathrm{m}^{2} \cdot \mathrm{K}$

\subsubsection{Logarithmic Mean Temperature Difference} (LMTD):

$$
\begin{aligned}
\theta_{m} & =\left\lfloor\frac{\left[\left(T_{h 1}-T_{c 2}\right)-\left(T_{h 2}-T_{c 2}\right)\right]}{\ln \left[\frac{\left(T_{h 1}-T_{c 2}\right)}{\left(T_{h 2}-T_{c 2}\right)}\right]}\right] \\
& =\left[\frac{[(85-45.07)-(65-45.07)]}{\ln \left[\frac{85-45.07}{65-45.07}\right]}\right]
\end{aligned}
$$

$\theta_{m}=28.78^{\circ} \mathrm{C}$

\subsubsection{Area required:}

$Q=U A \theta m$

$A=\left(\frac{20970}{2858.81 \times 28.78}\right)$

$A=0.2548 \mathrm{~m}^{2}$ 
So, total area required, $\mathrm{A}=0.2548 \mathrm{~m}^{2}$.

Area of single plate $=0.020 \mathrm{~m}^{2}$.

Total number of plates $=13$.

\subsection{EXPERIMENTAL SETUP}

\subsubsection{Test setup}

The experimental setup consists of a corrugated PHE, thermocouples, rotameter, manometer, centrifugal pumps and reservoirs. Heat exchanger has total 14 plates. The plate material is stainless steel AISI 316. Each plate has thickness of $0.5 \mathrm{~mm}$. The total heat transfer area is $0.2548 \mathrm{~m}^{2}$. It has height of $231 \mathrm{~mm}$, width of $90 \mathrm{~mm}$ with plate spacing of $2.25 \mathrm{~mm}$. Fluid flow is varied by rotameter in the range of 0.11 to $0.25 \mathrm{~kg} / \mathrm{sec}$. Four thermocouples are induced to measure varying temperature of working fluid at inlet and outlet of PHE. In order to take advantage of pumping power, water from reservoirs is pumped to inlets of PHE through two centrifugal pumps of $0.5 \mathrm{HP}$.

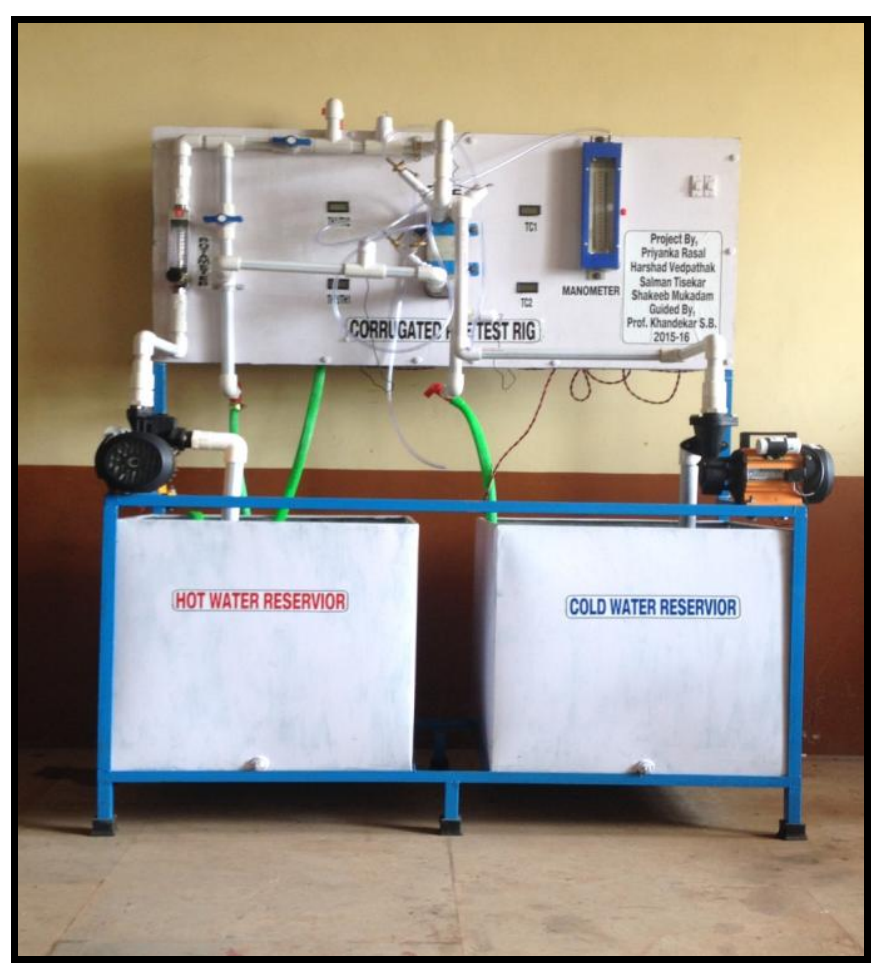

Fig-1: Experimental setup of corrugated PHE

\subsubsection{Test Procedure}

The corrugated PHE is used for trials. The working fluids used are hot and cold water. Two flow arrangements are implemented which are parallel and counter flow. Trials are conducted with variable mass flow rates of hot water and mass flow rate of cold water is kept constant. Procedure is repeated for getting more accurate results.

\section{RESULTS AND DISCUSSION}

For water-water heat transfer different results are plotted based on different parameters such as heat transfer coefficient, exchanger effectiveness, mass flow rate, Reynolds number and different flow arrangement.

\section{A) For parallel flow}

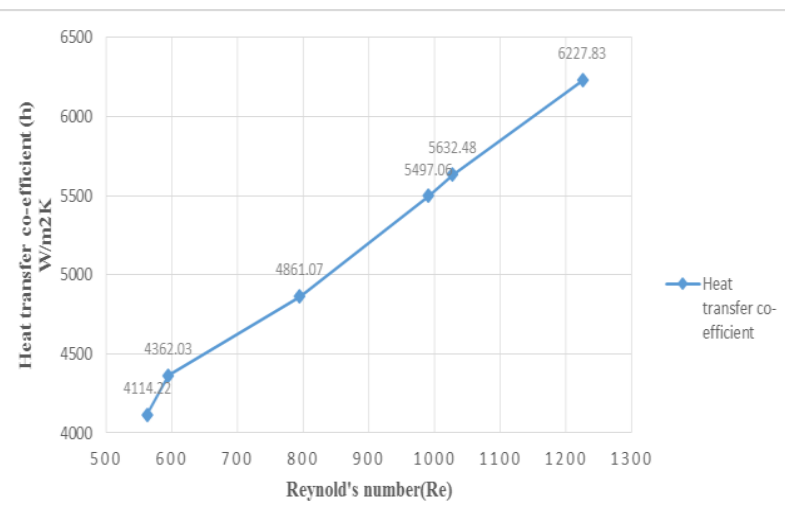

Chart-1: Heat transfer coefficient Vs Reynolds number

Chart-1 shows variation of convective heat transfer coefficient with Reyonlds number. It is observed that heat transfer coefficient increases with increase in Reynolds number. Increase in Reynolds number is attributed to more turbulent flow and it leads to higher heat transfer rate.

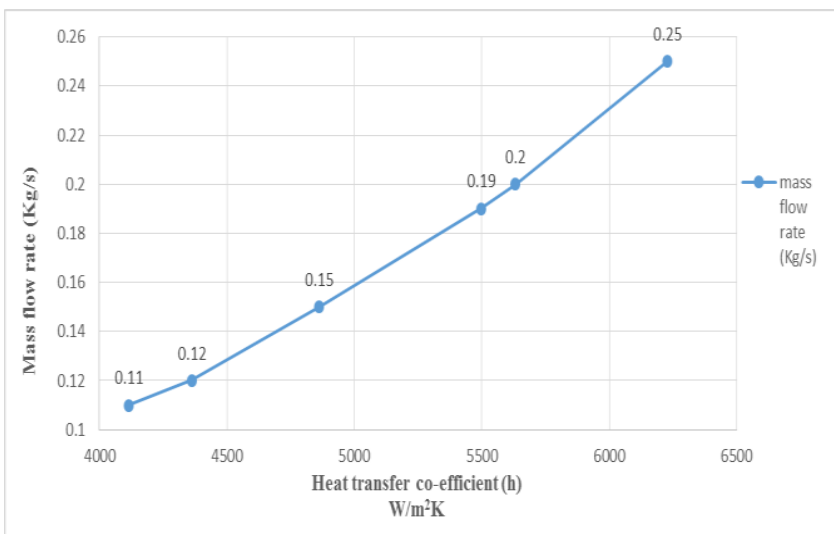

Chart-2: Mass flow rate of hot fluid Vs Heat transfer coefficient

Chart-2 shows variation of convective heat transfer coefficient with respect to mass flow rate of hot fluid. Increase in mass flow rate results into increase in flow velocity of fluid, it leads to increase in Reynolds number which ultimately increases heat transfer rate.

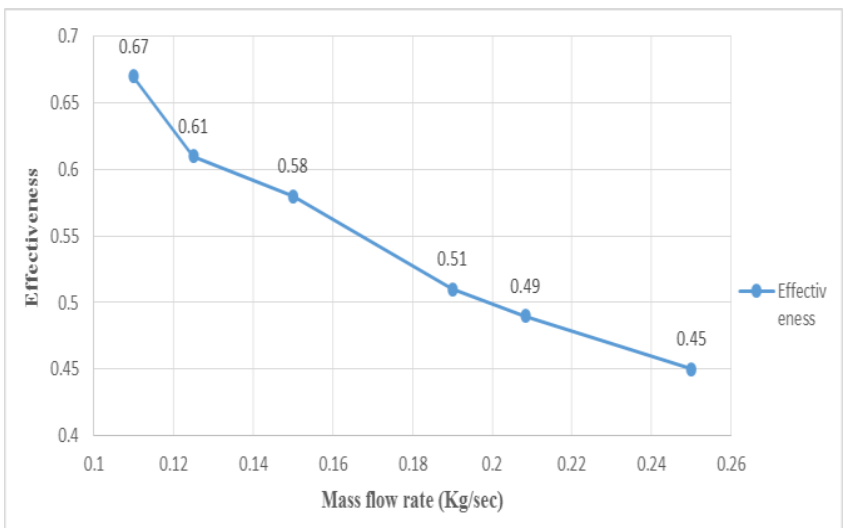

Chart-3: Effectiveness Vs mass flow rate of hot fluid 
Chart-3 shows variation of effectiveness with mass flow rate of hot fluid. It is observed that mass flow rate of hot fluid increases, effectiveness decreases. Due to increase in mass flow rate time elapsed for heat transfer between two fluids goes on decreasing resulting into a lesser temperature drop. Effectiveness is found to be maximum for minimum mass flow rate of hot fluid.

\section{B) For counter flow}

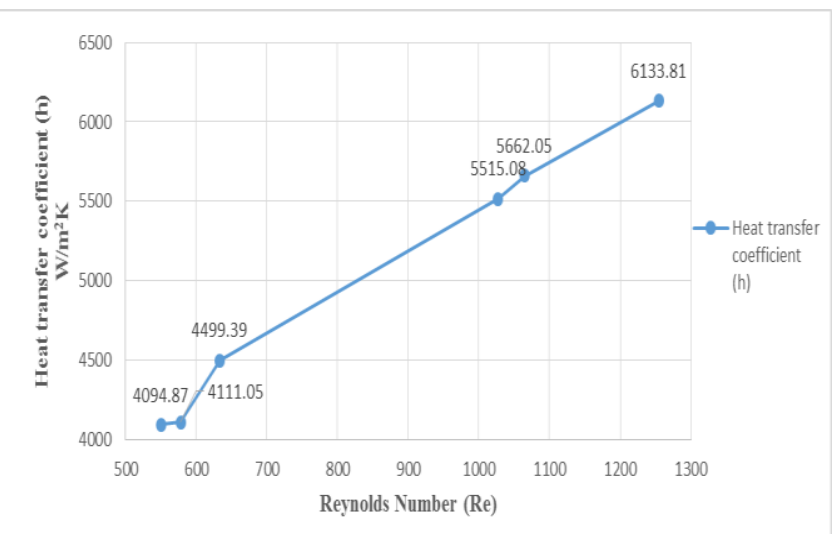

Chart-4: Heat transfer coefficient Vs Reynolds number

Chart-4 shows variation of convective heat transfer coefficient with reyonlds number. It is observed that heat transfer coefficient increases with increase in reynolds number. Increase in reynolds nuumber is an indication that flow is becoming more turbulent and results into higher heat transfer rate.

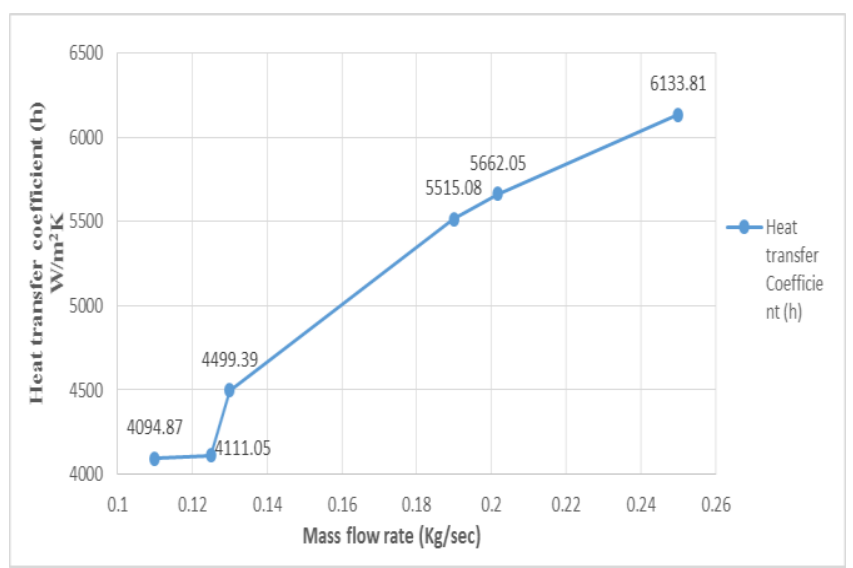

Chart-5: Heat transfer coefficient Vs Mass flow rate

Chart-5 shows variation of convective heat transfer coefficient with respect to mass flow rate of hot fluid. Increase in mass flow rate results into increase in flow velocity of fluid, it leads to increase in Reynolds number which ultimately increases heat transfer rate.

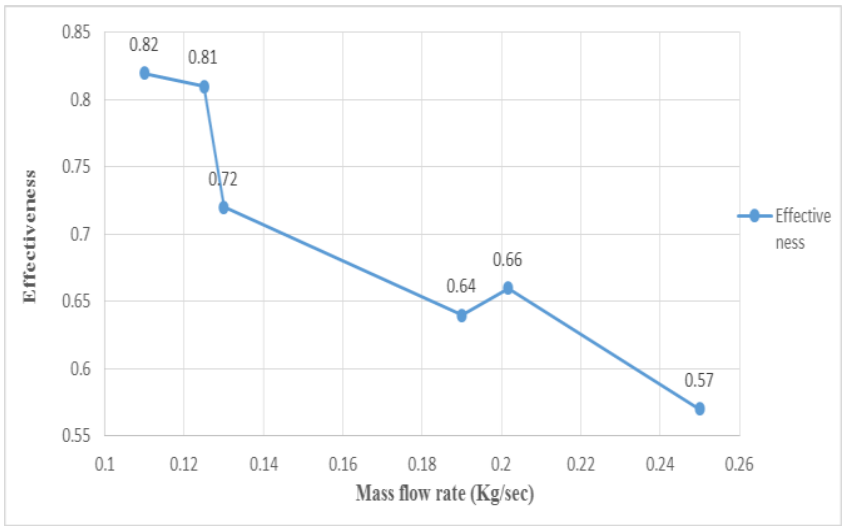

Chart-6: Effectiveness Vs Mass flow rate of hot water

Chart- 6 shows variation of effectiveness with mass flow rate of hot fluid. It is observed that mass flow rate of hot fluid increases, effectiveness decreases. Due to increase in mass flow rate time elapsed for heat transfer between two fluids goes on decreasing resulting into a lesser temperature drop. Effectiveness is found to be maximum for minimum mass flow rate of hot fluid.

\section{CONCLUSION}

This research work is focused on heat transfer analysis of corrugated PHE and also to investigate experimentally the performance of corrugated PHE with regard to convective heat transfer coefficient, heat exchanger effectiveness and to test the effect of varying mass flow rate of working fluid on effectiveness. Following are the findings of this experimental investigation:

- Convective heat transfer coefficient increases with Reynolds number and mass flow rate for both parallel and counter flow arrangement. This is due to the fact that flow becomes more turbulent and cause for turbulence can be attributed to plate geometry i.e., corrugations as well as high flow velocity.

- Effectiveness of heat exchanger decreases with increase in mass flow rate of hot fluid. Maximum effectiveness for parallel flow arrangement is 0.67 and that of for counter flow arrangement is 0.82 .

This experimental investigation on corrugated PHE can be extended with multi-phase working fluids such as oil to water. This work can be further extended for heat transfer analysis of nanofluids.

\section{REFERENCES}

[1] R. K. Shah and D. P. Sekulic, "Fundamentals of Heat exchanger design" (2003)

[2] R. K. Shah and S. G. Kandilkar "Multipass Plate Heat Exchangers- Effectiveness-NTU Results and Guidelines for Selecting Pass Arrangements" Vol.111, MAY (1989)

[3] Jogi Nikhil G., Lawankar Shailendra M. "Heat Transfer Analysis of Corrugated Plate Heat Exchanger of Different Plate Geometry", International Journal of Emerging Technology and Advanced Engineering, ISSN 2250-2459, Volume 2, Oct(2012) 
[4] Murugesan M.P. and Balasubramani R. "The Experimental Study on Enhanced heat Transfer Performance in Plate Type Heat Exchanger" Research Journal of Engineering Sciences, Vol.2(2),16-22,February (2013),ISSN 2278-9472.

[5] Vishal R. Naik, V.K. Matawala "Experimental Investigation of single phase Chevron Type Gasket Plate Heat Exchanger", International Journal of Engineering and Advanced Technology(IJEAT), ISSN: 2249-8958, Volume2, Issue-4,April 2013.

[6] T K S Sai Krishna, S G Rajasekhar, C Pravarakhya "Design and Analysis of Plate Heat Exchanger with $\mathrm{CO}_{2}$ and $\mathrm{R} 134_{\mathrm{a}}$ as working fluids", International Journal of Mechanical Engineering and Technology (IJMET),ISSN 0976-6359 Volume 4. Issue 4 July-August (2013)

[7] Masoud Asadi, Ramin Haghighi Khoshkhoo "Effects of Chevron Angle on Thermal Performance of Corrugated Plate Heat Exchanger", International Journal of Engineering Practical Research (IJEPR) Volume 3 Issue 1, February 2014.

\section{BIOGRAPHIES}

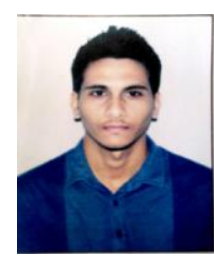

Tisekar Salman Waheed, student of B.E (Mechanical Engineering) and working on project of "Corrugated PHE" under the guidance of prof. S.B. Khandekar.

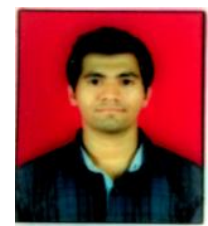

Mukadam Shakeeb Ashraf, student of B.E (Mechanical Engineering) and working on project of "Corrugated PHE" under the guidance of prof. S.B. Khandekar.

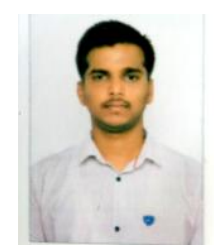

Vedpathak Harshad Sadanand, student of B.E (Mechanical Engineering) and working on project of "Corrugated PHE" under the guidance of prof. S.B. Khandekar.

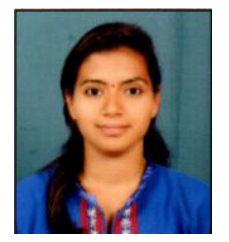

Rasal Priyanka K, student of B.E (Mechanical Engineering) and working on project of "Corrugated PHE" under the guidance of prof. S.B. Khandekar.

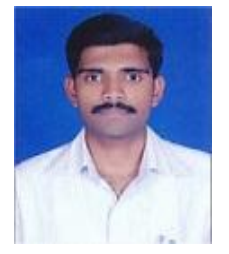

Prof. Khandekar Shailesh B. M.E. (Mechanical Engineering) working as assistant professor in department of Mechanical Engineering at Rajendra Mane College of Engineering and Technology, Devrukh, (University of Mumbai) 